DOI: $10.1515 /$ hssr -2017-0023

\title{
European Union: Spearhead of the Environment Protection Movement
}

\author{
Sorin Burnete*, Abiola E. Ogunmokun**
}

\begin{abstract}
Industrialization laid the foundation for contemporary civilization but also begot environmental problems, which have been building up and remained unsolved to this day. There is widespread belief that, if industrial manufacturing lies at the root of environment degradation through endless spewing of residual waste, trade among nations is to blame for scattering residual waste the world over. Yet paradoxically, it is the very international trade that might be the ground for major remedies thereto. The $20^{\text {th }}$ century witnessed the shift from free trade to fair trade; it is about time to shift from fair trade to clean trade.

Nevertheless, such serious problems had barely been dealt with until the post-World War II period. An awareness-raising effort in this line was made by the European Union (EU) which, since the early 1970s, has been dealing with environmental and social issues, especially the ones deriving from international trade, in a decisive and responsible manner. Still, EU's new policy in the field of environment protection has a downside in that it affects trade relations with partners from outside the Union, both developing and developed countries, thereby drawing fierce international reaction. The good part is that EU's actions will most likely prompt other nations to follow suit.
\end{abstract}

\footnotetext{
"Department of Management, Marketing and Business Administration, The "Lucian Blaga" University of Sibiu, Romania, 10, Victoriei Bvd., 550024, Sibiu, Romania; sorin.burnete@gmail.com

** Bucharest Academy of Economic Studies, 6 Romana Square, 010374 Bucharest, Romania; Council for Doctoral Studies - Economics and International Affairs; abiolaogunmokun@yahoo.com
} 
Keywords

industrialization, environment degradation, international trade, environmental policy

JEL Classification: N 50, F18

\section{Historical roots of environment degradation}

Environment degradation is deeply rooted in modern industrial revolutions. Large-scale industrialization, besides its unquestionable benefits, triggered a systematic assault on environment health. The switch from production in tiny manufacturing plants to factory-type mass production entailed the processing by the latter of huge quantities of inputs, in the form of raw materials and energy, turning out vast quantities of merchandise to be sold on both domestic and foreign markets. Concomitantly, tremendous capitals were invested in machinery, equipment and installations such as blast furnaces, rolling mills, steam engines, mechanical spinners and looms etc., failing which, large scale production is unconceivable. Following these developments, the processing plant paradigm became entrenched.

Industrialization equally produced profound social effects. At the beginning of the $19^{\text {th }}$ century, although industrialization was in full swing, particularly in England, the population of western countries was still massively concentrated in rural areas. Cities seldom numbered more than one hundred thousand inhabitants (Brunet, 1990). Industrial expansion triggered a massive shift of population from villages to cities, mostly in search of work, as well as a more accelerated progress of urban areas in terms of living standards and civilization.

Yet the downside of industrial development lies in its pernicious effects upon the environment, whose condition has been worsening continuously due to huge amounts of waste being dumped or disposed of in the open air, in rivers and into the soil. Factories would release toxic smokes into the air while discharging pollutants and chemicals specifically into waterways and streams, causing widespread air and water contamination. Concomitantly, thanks to advances in technology, a surge in the world's population ensued, with the natural upshot that there were more 
individuals consuming more natural resources. This led to the depletion of natural resources: vast areas were deforested to cope with growing urban communities.

\section{More industry: increased pressure on the environment}

The first industrialization tide swept uniquely over the more advanced Western World, other areas being, with a few exceptions, bypassed. The latter remained overwhelmingly oriented towards primary production. (Szirmai, 2009) This type of international economic order clearly condemned scores of nations to endless underdevelopment. The latter's drama was realistically emphasized by economists: “... regions, which are the most underdeveloped and feudal-seeming today, are the ones which had the closest ties to the metropolis in the past. They are the regions which are the greatest exporters of primary products to, and the biggest sources of capital for, the world metropolis and which are abandoned by the metropolis when for one reason or another business fell off." (Frank, 1966)

In the second half of the $20^{\text {th }}$ century, particularly after World War II, most developing nations embarked upon industrialization, with a view to diminishing their economic dependence on the West and fostering economic growth. Yet industrialization in the developing world greatly differed from the similar process that had unfolded in the west during the $19^{\text {th }}$ century in that the former failed to create new industries but simply shifted the existing old ones from the North (the conventional name for western developed countries located in the northern hemisphere) to the South (the conventional name for developing countries in the southern hemisphere). The process was hastened by the tightening up of environment regulation in western countries. The imposition by industrialized countries' governments of rules and constraints in respect to environment protection meant higher costs for western producers, which dented their international competitiveness. The solution lay "next door": in most developing countries such regulation did not even exist.

Industrial-type development has fundamentally changed the international division of labor, instituted by the first industrial revolution, which had rendered world trade structurally polarized: countries of the underdeveloped South would export raw materials and basic foodstuffs in 
exchange for processed goods (machinery etc.) from the industrialized North. Most developing nations rightfully considered this kind of international division of labor, not only unjust but highly unfair because it exposed the latter to intense price fluctuations currently occurring on the markets of their export goods, whereas markets for processed goods generally enjoy greater stability. Industrialization of the South ushered in a different type of international division of labor, mostly intra-sectorial: industries that had developed during the $19^{\text {th }}$ century industrial revolution (e.g. iron and steel, textiles etc.), which are the worst polluters and greatest energy consumers, gradually shifted toward developing countries, while developed nations embraced a new type of technological revolution by boosting Research and Development - intensive branches, mostly telecommunications and information processing. Needless to say, the latter pollute less and consume less energy and raw materials. The corollary: the gravity center of environment degradation shifted from North to South.

Ironically, the industrialization of developing nations, though stepping up the latter's economic development, placed them in an awkward position within the international division of labor, in at least two fashions: firstly, a lot of poor nations began to specialize in collecting waste and re-cycling, which are indeed labor intensive activities. As economists remarked with non-dissimulated irony (e.g. Hudson, 2009), moving such activities to peripheral countries was justified as creating employment there. Secondly, having taken over the polluting industries from the North, developing nations automatically became exporters of the products the respective industries turn out. Yet such exports are now subject to developed countries' environment standards or else risking denial of entry the latter's markets. The problem is that most developing nations lack the necessary means to comply with developed countries' environment conditions, which places their exports in jeopardy.

\section{The impact of international trade}

The expansion of world trade following the industrial revolutions further worsened the consequences upon the environment. Yet trade itself is not to blame for environment degradation. After all, trade is essential to economic development. In the absence of trade, industrialization makes little economic sense. No industry could survive in the long run if designed 
for the domestic market only. On the contrary, national economies tend to specialize internationally in order to gain comparative advantage, thereby turning their natural and human resources to better account. Foreign markets offer appealing prospects for goods producers, in terms of diversification, economies of scale and scope, prestige enhancing etc. Yet the tough international competitiveness race, fueled by growth in and liberalization of international trade, profitable though it is for nations' wellbeing, turned out to be ever harmful for the environment. In order to collect export earnings, nations would relentlessly boost export production, most often overlooking the serious harm they are inflicting upon environment and human rights, which may be either reversible or irreversible. It is for this reason that the link between trade and environment is still a hotly-debated issue on both national and international level.

The impact of trade upon the environment depends on several factors, which are often contradictory. We shall mention two of them. Firstly, nations' tendency to specialize according to comparative advantage places developing nations in an awkward position within the international division of labor. As we showed earlier, by virtue of this tendency, scores of developing nations, which find it hard to respond to rich countries' environmental policies, have been specializing and exporting products that are less environmentally friendly. Another factor, acting in the opposite direction, is related to the evolution of the world demand for developing countries' export goods, which dwindles as rich countries keep pushing for cleaner environment. Actually, the richer a nation becomes, the stronger the demand for a clean environment. (Trebilcock\&Howse, 2007)

The switch to a different international division of labor, which shifted environment pollution southward, had dire consequences for the newly industrialized countries, not only in respect to the state of the environment but also to the respective countries' international competitiveness. Pollution, to start with, is more severe in developing than in developed countries. Furthermore, the former are faced with a dearth of technologies to combat pollution, due to their limited financial possibilities. Yet ironically, even if they did possess such means, combating pollution would still be problematic due to their high dependence on exports of raw materials and basic products. Exploitation of oil in Nigeria for example, 
has caused substantial land, water and air pollution; yet since oil exploitation and production are vital for the country's development and fight against poverty, they will most likely continue regardless of the progress in environment protection. Briefly, exploitation and processing of most natural resources are indeed an economic lifeline for developing economies, yet they are dangerously damaging for the environment.

Globalization has further aggravated environmental problems because many such problems have become global. Pollution spillovers are quite common in today's world. The reverse of the coin is that the more a serious issue such as environment pollution becomes global, the higher the awareness of the danger and the likelihood that someone will eventually be stirred to action. Despite resources and ecosystems being under nobody's jurisdiction or sovereignty (Ostrom, 1990), they are still commonly shared by all nations of the world. It is for these reasons that international cooperation is the only way in which environmental degradation might be fought against effectively. Reality has shown that the problem can be, if not solved, at least mitigated, through appropriate taxes or regulations which everybody should observe.

\section{A belated yet blessed awakening}

Its harmful effects notwithstanding, environment pollution continued unabated along the entire $19^{\text {th }}$ and the first half of the $20^{\text {th }}$ century. In spite of pollution having become not only highly obvious but also hard to bear, people at large would be hardly aware of its bad effect on life. (Kasa, 2008) Odd though it may seem, vital environment problems were practically ignored until the post-World War II period. Although modern environmental laws began to be passed in the mid-nineteenth century on a national level, no serious, organized actions were undertaken internationally.

In the early 1970s, the effect of environmental policies on trade and the effect of trade on the environment were recognized. However, as a result of the effect of social advancement and economic growth on the environment, a worldwide gathering on the most proficient method to deal with the human condition was prompted. The 1972 Stockholm Conference was the reaction. Environmental policies began to have an increasing impact on trade between 1971 and 1991; so also the impact of 
trade on the environment become a widespread issue and this led to a number of discussions like the Tokyo Round of trade negotiations, the Uruguay Round and so on. During these discussions, certain environmental issues were addressed and there were noticeable developments in environmental forums. A firm stance was taken by the United Nations, according to which, environment and trade goals can be made complementary and mutually supportive through adequate national environmental policies. (United Nations, 2005) A no less important role belongs to the World Trade Organization (WTO), which manages the worldwide guidelines of trade between countries. Its fundamental capacity is to guarantee that trade flows occur unfettered. Part of the basic objectives of WTO are sustainable development and the protection and preservation of the environment. (WTO, 2004, 2015) To complement this objective, strategies are put in place to diminish exchange hindrances and dispose of discriminatory treatment in universal exchange relations. WTO rules allow members to embrace exchange related measures aimed at environmental protection and gives no room for its abuse by protectionist. WTO also adds to assurance and protection of nature through its target of exchange openness, through its standards and implementation instrument, through work in various WTO bodies, and through continuous endeavors under the Doha Development Agenda. The Doha Agenda incorporates particular transactions on trade and environment and a few undertakings allotted to the customary Trade and Environment Committee.

\section{European Union: early whistle-bloweron the scourge of environment degradation}

The lack of action on the purpose of saving the environment also characterized the two decades after World War 2.A consciousness-raising effort in this line was made by the European Union (EU). Since the early 1970s, the Community has been dealing with environmental and social issues, especially the ones deriving from international trade, in a more decisive and responsible manner. The starting point was the 1972 Summit of heads of state and government of the then European Economic Community (EEC), followed, in 1973, by a special meeting on environmental issues, on which occasion the first Environmental Action Program (EAP) was adopted. The document enshrines EEC' 
commitments toward objectives such as: prevention, reduction and containment of environment damage; conservation of ecological equilibrium; the rational use of natural resources, and so on. After 1980 the environmental standards issue enjoyed increasing importance, including the relation between the internal market and environmental policies. EAPs strongly rely on the necessity that environmental protection targets should smoothly fit into the internal market. As a consequence: firstly, environment protection standards have topped the agenda of technical barriers removal talks. Secondly, there is consensus that the paramount goal of embedding the environment protection strategy into the internal market mechanism can only be achieved by overhauling the entire production process, with special focus on the impact of strategic economic sectors on the environment. Thirdly, the strategy requires legislation improvement, starting with regulation of basic environmental issues. For example, the Integrated Product Policy (IPP) aims to promote the better environmental performance of products throughout the Internal Market. The goal is to identify products and services that have a reduced environmental impact throughout their life cycle, from the extraction of raw materials through to production, use and disposal. ${ }^{1}$

However, because hindrances to trade means costlier merchandise, primarily harming individuals in poor or developing nations that depend on this exchange, as an effort to encourage free trade, the European Union intends to assume a key part in keeping markets open worldwide, opening up business sectors with key partner nations and so forth. Therefore EU's newly-adopted policy in the field of environment protection should not be tagged as protectionist in its own right. Vying for a clean environment has nothing to do with mercantilism.

\section{Environment protection: an ethical icon in contemporary international trade}

Despite its unquestionable merits, the European Union's new environmental policy still has a downside in that it seems to gravely affect commercial relations with its trading partners, both developing and developed countries. Producers from outside the EU who fail to comply with the new regulations and standards will be subject to fines and penalties that can go as far as the loss of the right to sell on the single 
European market etc. It is then no surprise that the new policy has drawn fierce international reaction. Many countries throughout the world adopted retaliatory measures in the form of similar regulations.

Developed countries have stressed the difficulties they are encountering in complying, including the need to substitute traditional chemicals with accepted alternatives. EU's environmental policy has stirred counterreactions in the Americas because the rules oblige producers, especially in the electronic industries, to seek substitutes for the restricted substances. No less concerned are manufacturers in South Asian exporting countries, who see their commercial ties with the EU seriously menaced. Regrettably, the fierce disputes around the rules have affected mutual trade. On the other hand, EU's trading partners are aware that they must follow suit and enact similar environmental laws in order to protect their environment and their own citizens' health.

If developed countries are most likely find a way to surmount the "crisis" eventually, for developing countries the situation is by far more grinding given their heavy dependence on foreign markets, the EU market in particular. In order to comply with EU's environmental rules, the latter will be compelled to revise their export industries entirely, which obviously means higher costs for them. Higher costs may affect their competitiveness on the EU single market. On the other hand, developing nations are fully aware that EU's rules are entirely justified by the urgency to stop environmental degradation, not only in EU member countries but everywhere in the world. Therefore the developing world will have to struggle to comply in spite of high costs.

The problem is nonetheless thornier than it seems. The developing countries' denunciation of environmental standards as hidden protectionism is often blatantly labeled, especially by multinational companies, as an attempt to dodge fair competition, even social dumping that should be barred through countervailing measures. (Bhagwati, 2005)

\section{Conclusion}

It would not be exaggerated to state that environment-biased policies were pioneered by the EU. "Toward a cleaner Europe" has become the motto of the Community. Yet imposing the new trend is not easy because $\mathrm{EU}$ is not an isolated entity; on the contrary, it lies at the core of the global 
system. Unfortunately, the majority of nations, most of which are EU trade partners, lag behind in this struggle. Developing countries, especially the poorest ones are divided: some look unprepared, others seem reluctant to take concrete steps for the containment of environment deterioration. Yet there seems to be a tacit consensus among the latter: the path opened by the EU is right and it must be followed.

\section{References}

Bhagwati, J. (2005). In Defense of Globalization, Oxford University Press.

Brunet, A. (1990). La civilization occidentale, Hachette

Daniels, R. (1997). The Stalin Revolution: Foundations of the Totalitarian Era, New York: Houghton Mifflin.

Frank, A., G. (1966). The Development of Underdevelopment, New Yok, Monthly Review Press, 1970, available at: http://www.bresserpereira.org.br/ terceiros/cursos/2010/1970.the_development_of_underdevelopment.pdf

Hudson, R. (2009). The cost of globalization: producing new forms of risk to health and well-being, Risk management, vol. 11, nr.1, pp.13-29, available at:http://www.palgrave-

journals.com/rm/journal/v11/n1/full/rm200813a.html

Kasa, Sjur. (2008). Industrial revolutions and environmental problems, Research Gate, available at http:/ / www.researchgate.net/publication/237288842

Ostrom, E. (1990). Governing the Commons. The Evolution of Institutions for Collective Action, Cambridge University Press

Szirmai, A.(2009). Industrialization as an engine of growth in developing countries, 19502005, United Nations University, Working Paper Series \#2009-010, available at: www.meri.unu.edu

Trebilcock, M.J., Howse, R. (2007). The Regulation of International Trade, $3^{\text {rd }}$ ed., Routledge

WTO.(2004). Trade and Environment at the WTO, World Trade Organization Secretariat

WTO.(2015). Trade and Environment, available at: https://www.wto.org/ english/tratop_e/envir_e/envir_e.htm

${ }^{1}$ Seven EAPs have been adopted so far, the last one strengthening the necessity to secure further sound economic growth until 2020. EAPs' provisions are to be put into practice jointly by EU institutions and the member states. As a whole, the program is focused on such issues as climate 
change, biodiversity, environment and health, and sustainable management of resources and wastes. It also contains a number of regulations on various domains such as: chemicals (the Registration, Evaluation, Restriction and Authorization of Chemicals regulation, aka REACH); electrical and electronic equipment (the WEEE respectively RoHS directives.) (European Commission. 2006. EUR-Lex, Regulation (EC) No 1907/2006 concerning the Registration, Evaluation, Authorisation and Restriction of Chemicals (REACH) and establishing a European Chemicals Agency, available at http://ec.europa.eu/enterprise/ sectors/chemicals/reach/index_en.htm; European Commission. 1996. EURLex, RoHS Directive 2002/96 EC, available at: http://eur-lex.europa.eu/legalcontent/EN/TXT/?uri=CELEX:32002L0096)

\section{Biographical notes}

Sorin Burnete, Ph.D., is Professor of Economics at the Lucian Blaga University of Sibiu. His academic background was completed by a one year training at the University of Missouri. He was, for six years consecutively, visiting professor at J.W. University of Frankfurt/Main. He authored a number of books, monographs, textbooks dealing with many a topic in such fields as international trade, economic policy, international business, economic history, central banking. He also published several articles in international journals such as: "Romania's Economic Policy - the Rulers' Wisdom Will Lead Us" (Journal of Organizational Change Management); "New EU Member Countries are Phasing Out Labor-Intensive Activities: An Econometric Approach" (Studies in Business and Economics) etc.

Abiola E. Ogunmokun holds a Master degree in Business Administration and Engineering (MBA) from University Politehnica of Bucharest, Romania and a Bachelor of Science (B.Sc.) degree in Economics from Bowen University, Nigeria. She is currently undergoing her doctoral $\mathrm{PhD}$ studies in Economics and International Business at the Bucharest University of Economic Studies, Romania. In 2010, she served as one of the facilitators for the Millennium Development Goals (MDG) in Nigeria. Her scientific interests include business internationalization and developmental economics. 